\title{
Lymphocytes in Alzheimer's disease pathology: Altered signaling pathways
}

\author{
Noemí Esteras ${ }^{1,3^{*}}$, Carolina Alquézar ${ }^{1 *}$, Ana de la Encarnación ${ }^{1}$ and Ángeles \\ Martín-Requero ${ }^{1,2}$
}

\begin{abstract}
${ }^{1}$ Department of Cellular and Molecular Medicine, Centro de Investigaciones Biológicas (CSIC), Ramiro de Maeztu 9, 28040 Madrid, Spain. ${ }^{2}$ Centro de Investigación Biomédica en Red de Enfermedades Raras (CIBERER) Madrid, Spain. ${ }^{3}$ Present address, Department of Molecular Neuroscience, Institute of Neurology, Queen Square, London, WC1N 3BG
\end{abstract}

* These authors contributed equally to this work

Key words: Alzheimer's disease, lymphocytes, cell cycle, apoptosis, signaling pathways, mitochondrial dysfunction, proteasome.

Address for correspondence:

Dr. Ángeles Martín-Requero

Centro de Investigaciones Biológicas (CSIC)

Ramiro de Maeztu 9

28040 Madrid, SPAIN

Phone: 34-91-837-3112

Fax: 34-91-536-0432

E-mail: amrequero@,cib.csic.es 


\begin{abstract}
Alzheimer's disease (AD) is a neurodegenerative disorder marked by progressive impairment of cognitive ability. Patients with AD display neuropathological lesions including plaques, neurofibrillary tangles, and neuronal loss in brain regions linked to cognitive functions. Despite progress in uncovering many of the factors that contribute to the etiology of this disease, the cause of neuronal death is largely unknown. Neuroinflammation seems to play a critical role in the pathogenesis of AD. Inflammatory processes in the brain are mainly mediated by the intrinsic innate immune system consisting of astrocytes and microglial cells, and cytokine, chemokine, and growth factor signaling molecules. However mounting evidence suggest that the Central Nervous System (CNS) is accessible to lymphocytes and monocytes from the blood stream, indicating that there is an intense crosstalk between the immune and the $\mathrm{CN}$ systems. On the other hand some AD-specific brain-derived proteins or metabolites may enter the plasma through a deficient blood-brain barrier, and exert some measurable signaling properties in peripheral cells. The goals of this review are: 1) to explore the evidences of changes in signaling pathways that could mediate both central and peripheral manifestations of $\mathrm{AD}$, and 2) to explore whether changes in immune cells, particularly lymphocytes, could contribute to AD pathogenesis.
\end{abstract}




\section{Introduction}

Alzheimer's disease (AD) is the most common neurodegenerative disorder with a prevalence of $11 \%$ in people age 65 and older and represents $60 \%$ of all cases of dementia [1]. It begins with a decline in cognition followed by a number of other changes in brain functioning, including impairments in language and visual-spatial skills, and disorientation. This impairment in cognitive functions is due to anatomical atrophy of $\mathrm{AD}$ brains, which correlates with severe neuronal loss. Neuropathological hallmarks are extracellular deposits of misfolded amyloid- $\beta(\mathrm{A} \beta)$ protein, so-called senile plaques and intracellular accumulations of hyperphosphorylated microtubuleassociated tau (neurofibrillary tangles, NFT). Although the molecular mechanisms of $\mathrm{AD}$ are still being unraveled, neuroinflammation has been reported to contribute to the pathophysiology of AD and late-onset neurodegenerative diseases [2]. Local immune responses involving glial cells and the complement system are activated in the AD brain $[3 ; 4]$. The cells responsible for the inflammatory reaction are microglia, astrocytes and neurons. These activated cells produce high levels of inflammatory mediators such as proinflammatory cytokines and chemokines, prostaglandins, leukotrienes, thromboxanes, coagulation factors, free radicals as reactive oxygen species and nitric oxide, complement factors, proteases and protease inhibitors, and C-reactive protein [5]. In addition, there is now strong evidence suggesting the involvement of a systemic immune response in $\mathrm{AD}$ [6]. Both increased concentrations of proinflammatory cytokines and changes in lymphocyte subsets, with an augmented percentage of immune cells expressing activation markers, are described in AD [7-9]. Thus, it seems that the brain and immune system are intricately connected and involved in significant crosstalk to maintain homeostasis. 
The communication pathways from peripheral sites of inflammation to the brain have been investigated in animal models [10]. It was reported that systemically generated inflammatory mediators signal to the brain via both neural and humoral routes in the blood $[11 ; 12]$. Cytokines such as interleukin-6 (IL-6), IL-1 $\beta$, and tumor necrosis factor (TNF) circulate in the blood and signal to the CNS via the circumventricular organs, which lack a patent blood-brain barrier (BBB) [13] or signal across the BBB via receptors expressed on the endothelium [14]. The presence of multiple pathways from the peripheral immune system to the brain highlights the importance of this signaling process. On the other hand, some AD-specific brain-derived proteins or metabolites may enter in the plasma through a deficient BBB, and exert some measurable signaling properties [15]. Indeed, significant changes in gene expression or at posttranscriptional level have been reported in freshly isolated peripheral blood mononuclear cells (PBMCs) from AD patients and non-demented controls [16-18]. Whether the systemic alterations represent a cause or consequence of the neurodegenerative process is still a controversial issue.

In this review we will summarize current knowledge of changes in signaling pathways in lymphocytes from $\mathrm{AD}$ patients and discuss the significance of changes in peripheral cells in $\mathrm{AD}$ pathogenesis.

\section{Altered signaling pathways in AD lymphocytes}

The concept of PBMCs as a "window" into the CNS was first proposed by Percy et al., in their comprehensive review of peripheral manifestations of AD [19]. Lymphocytes represent a useful material, easily accessible to study the biochemistry and molecular biology of the CNS and for investigating possible systemic derangements in neurodegenerative disorders. Based on this assumption, PBMCs have been widely used by several laboratories as an experimental model to investigate receptor signal 
transduction alterations searching for emerging biomarkers at peripheral level to implement the strategies for diagnostic and/or therapeutic approach in AD.

Expression profiling of PBMCs has disclosed dysfunction of pathways subserving signal transduction, lipid metabolism, mitochondrial bioenergetics, intracellular trafficking, proteasomal activity, and cell survival $[16 ; 17 ; 20]$. Among others, abnormal amyloid precursor protein (APP) expression, altered levels of antioxidant enzymes, oxidative damage to DNA, RNA and protein, deregulated cytokine secretion and augmented rates of apoptosis are features shared by AD brain and lymphocytes [18]. Moreover, lymphocytes express N-methyl-D-aspartate (NMDA), dopamine and acetylcholine receptors [21-23] thought to function primarily in the CNS. Therefore, in addition to classical immunological stimuli such as antigens, cytokines, chemokines and growth factors, they can be activated by neurotransmitters.

Here, we will focus on altered control of cell cycle and apoptosis, mitochondrial dysfunction, and changes in the proteasome activity as peripheral markers for detection of $\mathrm{AD}$ in lymphocytes.

\section{Cell cycle control failure in AD lymphocytes}

Increasing evidence suggest that neuronal cell cycle events underlie neurodegeneration. It is thought that in $\mathrm{AD}$ susceptible neurons re-enter an aberrant cell cycle, but since they cannot complete the cell cycle, they die [24-27]. Cell cycle re-entry appears to represent an early and critical event in $\mathrm{AD}$, leading to the development of AD-related pathology such as hyperphosphorylation of tau and $\mathrm{A} \beta$ deposition and ultimately inducing neuronal cell death [28; 29]. Several factors, including many of the identified risk factors for Alzheimer's disease, such as elevated plasma homocysteine levels, ageing, menopause, low thyroid levels, low level prolonged oxidative stress or head injury, can either represent mitogenic signaling for neurons or facilitate cell cycle re- 
entry in vulnerable neuronal populations [30]. On the other hand, the APP and A $\beta$ have mitogenic properties in vitro, and accumulation of growth factors have been found in diffuse amyloid deposits [31]. The rapid response of microglia and astrocytes to any disturbance in the CNS microenvironment results in an increased expression of specific cell surface receptors, and in the release of growth factors and cytokines, which may be protective acutely but, if not resolved, may contribute to cell cycle activation in vulnerable neurons. In addition and because of failure of $\mathrm{BBB}$ in $\mathrm{AD}$ [32], growth factors and cytokines can eventually activate the immune cells. Indeed cell cycle deregulation has been found in peripheral cells from AD patients such as lymphocytes and fibroblasts [33-39]. Similar to that described in $A D$ brain, the $G_{1} / S$ transition control mechanism fail in lymphocytes from AD subjects. In a early work by Nagy group, aimed specifically at the detection of any defects of the $\mathrm{G}_{1} / \mathrm{S}$ transition control, [35] was reported a significant reduction on the relative lengthening of the $G_{1}$ phase in response to cell cycle inhibitors in $\mathrm{AD}$ lymphocytes. Interestingly, the relative lengthening of the $\mathrm{G}_{1}$ phase distinguish lymphocytes from sporadic or familial AD patients [40]. In consonance with the idea that cell cycle disturbances are early pathogenic events in $A D$ brain, the $G_{1} / S$ control failure has been also detected in lymphocytes from Mild Cognitive Impairment (MCI) patients, a prodromal stage of AD $[35 ; 38]$.

During the beginning of the cell cycle at the $G_{1}$ phase, a variety of growth signals induce changes in cell cycle regulatory proteins. The $G_{1} / S$ transition is regulated by cyclin D, and E proteins, cyclin-dependent kinases (CDKs) CDK4/6, and cyclindependent kinases inhibitors (CDKIs) [41]. Cyclin D forms an active complex with its catalytic subunits CDK4/6-CDKs resulting in the phosphorylation and activation of the retinoblastoma protein (pRb) complexes to E2F1-DP1. Transcription factor E2F1 is 
almost exclusively localized in the nucleus and when co-expressed with its DNAbinding partner, DP1, it relocates from the cytoplasm to the nucleus forming activated E2F1-DP1 complex [42]. Protein complex pRb-E2F1-DP1 is a major regulator of the $\mathrm{G}_{0} / \mathrm{G}_{1}$-to-S-Phase transition. Initial phosphorylation of $\mathrm{pRb}-\mathrm{E} 2 \mathrm{~F} 1-\mathrm{DP} 1$ facilitated by complex cyclin D/CDK4/6 results in gene transcription of cyclin E. Cyclin E then binds to its catalytic subunit CDK2 forming active complex cyclin E/CDK2 which hyperphosphorylates $\mathrm{pRb}$ in the $\mathrm{pRb}-\mathrm{E} 2 \mathrm{~F} 1-\mathrm{DP} 1$ complex. Hyperphosphorylation of $\mathrm{pRb}$ causes disassociation and full activation of E2F1-DP1, thus allowing binding to and activation of E2F response elements in promoters of S-Phase cell cycle proteins. In addition CDKIs either from the CIP/KIP1 (p21 and p27) or the INK families (p16 and p18) play a predominant role in controlling the $G_{1} / S$ transition [43]. Evidences for changes in the expression levels of these cell cycle regulatory proteins in AD brain have been long recognized [24; 44]. Enhanced levels of phosphorylated pRb were found in $\mathrm{AD}[45 ; 46]$, and altered subcellular localization of the transcription factor E2F-1 was reported in AD brain [45; 47]. Several groups have described similar changes in cell cycle regulatory proteins in lymphocytes from late-onset AD. They are summarized in Table 1. 
TABLE 1

Changes in cell cycle regulatory proteins in lymphocytes from late-onset Alzheimer's disease patients.

\begin{tabular}{|c|c|c|c|}
\hline Protein & Role & Change & Reference \\
\hline $\begin{array}{l}\text { Cyclin D } \\
\text { Cyclin E }\end{array}$ & $\begin{array}{l}\mathrm{G}_{0} / \mathrm{G}_{1} \text { late } \mathrm{G}_{1} / \mathrm{S} \\
\mathrm{G}_{1} \text { to } \mathrm{G}_{1} / \mathrm{S}\end{array}$ & 个 & $\begin{array}{l}{[40]} \\
{[39]}\end{array}$ \\
\hline $\begin{array}{l}\text { CDK2 } \\
\text { CDK4 }\end{array}$ & $\begin{array}{l}\text { Late } \mathrm{G}_{1} / \mathrm{S} \\
\mathrm{G}_{1} / \mathrm{S}\end{array}$ & $\uparrow$ & $\begin{array}{l}{[39]} \\
{[17]}\end{array}$ \\
\hline $\begin{array}{l}\text { p21 } \\
\text { p27 } \\
\text { p16 }\end{array}$ & $\begin{array}{l}\text { Multi cyclin/CDK inhibitor } \\
\text { Cyclin D and E/CDK inhibitor } \\
\text { CDK4/CDK6 inhibitor }\end{array}$ & $\begin{array}{l}\uparrow \downarrow \\
\uparrow\end{array}$ & $\begin{array}{l}{[33 ; 40 ; 48]} \\
{[34 ; 39 ; 49]} \\
{[17]}\end{array}$ \\
\hline $\mathrm{pRb}$ family of proteins & CDK2/4/6 check point & $\uparrow$ & {$[34 ; 39 ; 50]$} \\
\hline E2F & $\begin{array}{l}\text { Transcriptional activator of } \\
\text { S-phase specific genes }\end{array}$ & $\uparrow$ & {$[39 ; 50]$} \\
\hline $\begin{array}{l}\mathrm{NF}-\kappa \mathrm{B} \\
\mathrm{p} 53\end{array}$ & $\begin{array}{l}\text { Transcriptional activator of cyclin D1 } \\
\text { Transcriptional activator of } \mathrm{p} 21\end{array}$ & $\begin{array}{l}\uparrow \downarrow \\
\uparrow\end{array}$ & $\begin{array}{l}{[50 ; 51]} \\
{[38 ; 40 ; 52]}\end{array}$ \\
\hline
\end{tabular}

While it is clear that failure of regulation of cell cycle occurs in neurons and peripheral cells in $\mathrm{AD}$, the signaling pathways that trigger these events are not well defined. The same or similar mitogenic signals in both brain and lymphocytes might alter cell cycle activity by activation of growth factor receptors or their signaling molecules (kinases or transcription factors).

Previous work from this laboratory aimed at studying the underlying signaling pathways involved in the enhanced proliferation of immortalized lymphocytes from AD patients $[34 ; 49 ; 53 ; 54]$. We investigated the effects of perturbing receptor signaling pathways by using inhibitors of protein-kinases or calmodulin (CaM), as well as pertussis toxin, on the proliferation of normal and AD lymphoblasts. We demonstrated that $\mathrm{Ca}^{2+} / \mathrm{CaM}$ signaling was overactivated in $\mathrm{AD}$ cells, as $\mathrm{CaM}$ antagonist were able to restore normal rates of cell proliferation $[34 ; 54]$. Increased activity of the $\mathrm{Na}^{+} / \mathrm{H}^{+}$ exchange and transcriptional alterations of E2F and NF- $\mathrm{B}$ (nuclear factor kappa-light- 
chain-enhancer of activated $\mathrm{B}$ cells) found in $\mathrm{AD}$ cells were also sensitive to CaM antagonists $[50 ; 54]$. Increased proliferation of AD lymphoblasts was causally linked to decreased levels of the CDK inhibitor p27 and enhanced phosphorylation of pRb protein $[34 ; 49 ; 53]$. Moreover, we reported that $\mathrm{Ca}^{2+} / \mathrm{CaM}$-dependent overactivation of phosphatidylinositol-4,5-bisphosphate 3-kinase (PI3K)/Akt signaling cascade in AD cells, plays an important role in regulating p27 abundance by increasing its degradation in the ubiquitin-proteasome pathway [53]. Half-life of p27 protein was markedly reduced in lymphoblasts from $\mathrm{AD}$ patients compared with that in control cells. Our results indicated that the increased phosphorylation of p27 at Thr187, rather than changes in the $26 \mathrm{~S}$ proteasome activity, is likely responsible for the enhanced degradation of $\mathrm{p} 27$ in AD cells. It was suggested that overactivation of PI3K/Akt in AD cells somehow facilitates phosphorylation of Thr187 by the cyclin E/CDK2 complex. In addition, PI3K/Akt phosphorylates other p27 residues (Thr157, Thr159), which are important in controlling the nucleo-cytoplasmic traffic of p27 [55]. The exclusion of p27 from the nucleus would then facilitate its degradation by the proteasome $[53 ; 56]$ and thus, relieving cyclin E/CDK2 kinase activity from p27 inhibition.

The importance of PI3K/Akt signaling pathway in $\mathrm{AD}$ brain was put forward by previous reports that linked this cascade with amyloid- $\beta$, neurofibrillary tangles and neuronal loss in AD brain. Increased phospho-Akt (Ser473) has been detected in AD temporal cortex neurons [57]. Furthermore, overactivation of Akt in AD brains is accompanied by increased levels of phosphorylation of Akt substrates such as glycogen synthase kinase $3 \beta$ (GSK3 $\beta$ ), mammalian target of rapamycin (mTOR), tau and lower levels of p27 [57; 58].

On the other hand, $\mathrm{Ca}^{2+} / \mathrm{CaM}$ overactivation of $\mathrm{PI} 3 \mathrm{~K} / \mathrm{Akt}$ in $\mathrm{AD}$ lymphoblasts was associated with higher CaM content than in control cells [59]. It was suggested that the 
increased $\mathrm{CaM}$ levels in $\mathrm{AD}$ cells synergize with serum to overactivate $\mathrm{PI} 3 \mathrm{~K} / \mathrm{Akt}$ pathway. In agreement with previous reports $[60 ; 61]$, we found that $\mathrm{CaM}$ is able to bind to the $85 \mathrm{KDa}$ regulatory subunit of PI3K (p85). Moreover it was observed a significant higher binding of $\mathrm{CaM}$ to $\mathrm{p} 85$ in $\mathrm{AD}$ lymphoblasts compared to control cells, thereby resulting in enhanced Akt phosphorylation.

The up-regulation of CaM levels in $\mathrm{AD}$ lymphoblasts is not the consequence of altered expression of any of the three different genes that encode CaM, but rather the result of decreased rates of CaM degradation [59]. It was shown that intracellular $\mathrm{Ca}^{2+}$ levels and reactive oxygen species (ROS) seem to control CaM degradation [59]. In AD cells, reducing the rate of degradation of $\mathrm{CaM}$ could be the cellular response to $\mathrm{Ca}^{2+}$ overload, since it is well documented higher levels of cytosolic free $\mathrm{Ca}^{2+}$ in lymphocytes from sporadic as well as familial AD patients [62-66].

A close association between alterations in $\mathrm{Ca}^{2+}$ homeostasis and cell cycle activity in $\mathrm{AD}$ cells was also found by other groups $[67 ; 68]$. In addition, $\mathrm{Ca}^{2+}$ dysfunction has been linked to changes in other cell survival signaling transduction processes. AD cells were shown to exhibit changes in the functioning of $\mathrm{G}$ proteins [69], activity of PKC [70; 71], and increased activity of IP3 receptor activity was reported in lymphocytes derived from familial AD patients $[62 ; 72]$.

Signaling molecules downstream PI3K/Akt such mTOR or GSK3 $\beta$, are altered in lymphocytes derived from $\mathrm{AD}$ patients $[35 ; 73 ; 74]$. mTOR is a highly conserved serine-threonine kinase that is essential for the co-ordination of intra and extra-cellular signals concerning cell growth, division and differentiation [75]. In the central nervous system, the mTOR pathway is known to play a key role in regulating synaptic remodeling [76], as well as modulating autophagy activity in neurons [77]. The first evidence that mTOR signaling was altered in peripheral cells from AD patients was 
reported by the Nagy's laboratory [35]. They found that AD lymphocytes showed a reduced response to rapamycin when compared with control cells. Later on it was demonstrated that alterations in mTOR signaling were associated with cognitive decline in $\mathrm{AD}$ [78]. The examination of the functional integrity of mTOR signaling in $\mathrm{AD}$ lymphocytes by gene expression analysis revealed that the up- or down- regulated mTOR genes were significantly enriched for 25 molecular and cellular functions including cellular growth and proliferation, cell cycle, and the main metabolic pathways [79]. Interestingly it was suggested that the assessment of the functional integrity of the downstream signaling cascade of mTOR from lymphocytes may reflect susceptibility to develop $\mathrm{AD}$ rather than provide an assessment of disease state, and therefore could be exploited diagnostically [79].

GSK3 $\beta$ the key enzyme in the control of glycogen synthesis is also involved in the regulation of critical intracellular signaling pathways, including cell cycle, gene expression and apoptosis [80-82]. The disruption of GSK3 $\beta$ homeostasis has been linked with the development of several diseases including AD. GSK3 $\beta$ activity is increased within the $\mathrm{AD}$ brain, favoring the hyperphosphorylation of microtubuleassociated protein tau and the formation of neurofibrillary tangles [83]. Moreover, the activation of GSK $3 \beta$ inhibits the cleavage of the APP protein, increasing the production of the amyloid- $\beta$ (A $\beta 42)$ peptide [84] and leads to memory impairment in animal models $[85 ; 86]$. Therefore, the deregulation of GSK3$\beta$ activity has major effects in key pathological features of $\mathrm{AD}$ and therefore is widely considered a therapeutic target of interest. Altered regulation of GSK3$\beta$ was also found in white blood cells and platelets from $\mathrm{AD}$ patients and $\mathrm{MCI}[73 ; 87]$. These observations suggested that the peripheral determination of GSK3 $\beta$ activity might be a useful diagnostic biomarker for early AD and a surrogate marker of early pathophysiological changes. 
GSK $3 \beta$ activity is also modulated by other relevant extracellular signaling pathways besides the PI3K/Akt; they are the insulin/insulin-like growth factor I (IGF-I), or the canonical Wnt pathways [88].

There is widening recognition that $\mathrm{AD}$ is closely linked to a state of relative insulin resistance in the brain $[89 ; 90]$. Levels of IGF-I, insulin and cognate receptors are deregulated in $\mathrm{AD}$ brain [91]. In normal brain, IGF-I and insulin promote glucose utilization, energy metabolism and neuronal survival [92], largely through PI3K/Akt/GSK3 $\beta$ signaling [93]. Insulin receptors populate neuronal synapses and astrocytes in memory-processing brain regions [94]. Acute insulin treatment improved memory in both humans and rodents [95-97]. On the other hand, increased A $\beta$ production prompts the onset of glucose intolerance and insulin resistance [98]. The insulin-induced activation of the PI3K/Akt/GSK3 $\beta$ is also blunted in peripheral ells from AD patients [99]. GSK3 $\beta$ plays a crucial role in the regulation of cell cycle events through its ability to phosphorylate $\beta$-catenin. Phosphorylated $\beta$-catenin is recognized by ubiquitin and targeted for proteasomal degradation [100]. Consequently, signals that modify GSK $3 \beta$ activity are expected to alter $\beta$-catenin levels. In the nucleus, $\beta$-catenin interacts with transcription factors TCF (T-cell factor)/LEF (lymphoid enhancing factor) [101] to activate genes that allow cell cycle progression as cyclin D1 and c-myc [102].

On the other hand, GSK3 $\beta$ has been identified as an important regulator of inflammation [103] promoting the production of several pro-inflammatory cytokines such as IL-6, IL-1 $\beta$, and TNF $\alpha$, as well as decreasing the levels of the anti-inflammatory cytokine IL-10. Data from Avila's group demonstrated that GSK3 $\beta$ overexpression in neurons leads to the appearance of a unique pattern of cytokines in the brain in vivo that is detrimental for appropriate neuron maturation [80; 104]. 
GSK $3 \beta$ is a key transducer of the canonical Wnt signaling, the components of which are involved in $\mathrm{AD}$ [105]. In the canonical pathway, members of the Wnt family interact with Frizzled, a seven-transmembrane receptor, and with an additional receptor that corresponds to either low-density lipoprotein receptor-related protein 5 (LRP-5) or LRP-6. Activation of this pathway leads to the inhibition of GSK3 $\beta$ through a cascade of intracellular reactions that involve protein kinases and adaptor proteins [102]. Inestrosa and coworkers have provided evidences that Wnt pathway is modulated by A $\beta$ in $\mathrm{AD}$ [106]. Moreover it has been suggested that Wnt pathway might play a role in the early induction of the cell cycle in neurons [107]. As far as we know, the role of Wnt signaling pathway on peripheral cells from AD patients has not been investigated.

\section{Impaired apoptosis in AD lymphocytes}

The molecular cascades leading to the loss of neuronal populations in AD have not been fully delineated. However it appears that apoptosis is the final fate of vulnerable neurons. Careful examination of brains after autopsy for signs of apoptosis has provided, compelling evidence that apoptosis is increased in $\mathrm{AD}$ brains compared with brains from non-demented [108]. Several markers of apoptosis, such as nuclear DNA fragmentation, and activation of caspases were reported to be elevated in AD brains $[109 ; 110]$.

It is now widely accepted that an aberrant re-initiation of the cell cycle activation in vulnerable neurons is one important inducer of neuronal apoptosis $[31 ; 111 ; 112]$. There is a significant body of evidence pointing to a role for neuronal cell cycle proteins in the modulation of stress-induced apoptosis, including the neuroprotective effects shown by certain CDK inhibitors [113]. Neuronal apoptosis, however, differ of classical apoptosis in the long time taken for susceptible neurons to die. It appears that they are highly protected against rapid apoptotic cell death. Even if the apoptotic cascade is initiated, 
the lack of the downstream caspases [114] leads to a long agony, instead of rapid apoptosis [115]. As a consequence, neurons survive for long periods of time in the $\mathrm{G}_{2}$ phase of the cell cycle becoming more vulnerable to stress according to the "two-hit hypothesis" [116; 117]. The need of two hit for effective neuronal death provides an explanation for the low amounts of neuronal apoptosis in AD (less than one in 10,000 at any given time show signs of apoptosis) [118]. This apoptosis avoidance, together with differences in the signal transduction pathways activated by growth factors in the brain, may represent a defense program for susceptible neurons in $\mathrm{AD}$, in analogy with neoplasia. Indeed some authors have considered AD pathology as an abortive neoplastic disorder [29]. Interestingly, lymphoblasts from sporadic AD patients show tumor-like features. Work from our laboratory demonstrated that compared with lymphoblasts from non-demented subjects, AD cells have a higher proliferative activity and increased resistance to apoptosis induced by serum deprivation $[50 ; 119]$. Selective impairment of mechanisms involved in cell death has been also reported in fibroblasts from AD patients. The protective mechanism of $\mathrm{AD}$ fibroblasts against $\mathrm{H}_{2} \mathrm{O}_{2}$ was related to an impairment of cell cycle arrest and a diminished induction of apoptosis [120].

Increased resistance of $\mathrm{AD}$ lymphoblasts to serum deprivation also depends on $\mathrm{Ca}^{2+} / \mathrm{CaM}$ signaling $[50 ; 119]$. Therefore, $\mathrm{CaM}$ seems to play a pivotal role in transmitting proliferative/survival signals from the plasma membrane to the nucleus. Whether CaM contributes to cell proliferation or apoptosis may depend on cellular CaM levels and/or activity, as well as the presence of growth-stimulatory signals. The lower vulnerability to death of $\mathrm{AD}$ cells was associated with decreased NF- $\mathrm{B}$ DNA-binding activity [50] and higher levels of the CDK inhibitor p21 [48; 121]. The involvement of NF- $\mathrm{BB}$ activation in inducing apoptosis was previously reported in HEK 293 cells [122] and conversely inhibition of NF-kB was shown to prevent cell death induced by the 
oncogenic protein, latent membrane protein 1 (LMP1) in Rat-1 cells [123]. Further work aimed at studying the molecular mechanism involved in the distinct $\mathrm{Ca}^{2+} / \mathrm{CaM}$ mediated regulation of survival of $\mathrm{AD}$ lymphoblasts revealed a CaM/CaMKIIdependent downregulation of the ERK1/2 signaling pathway [119]. It is well known that the kinetics and duration of ERK1/2 activation are important factors in determining the cellular response $[124 ; 125]$. In lymphoblasts derived from AD patients we observed an enhanced and transient activation of ERK1/2 in AD lymphoblasts associated with increased proliferation, whereas serum starvation induced a sustained activation of ERKs, although lower than in control cells. These results are in consonance with previous work in which a persistent activation of ERK1/2 was associated with cell cycle arrest and apoptosis in different cell types [126-128].

As already mentioned, the higher resistance of $\mathrm{AD}$ lymphoblasts to death induced by trophic factor deprivation was accompanied by increased levels of p21 [48]. Several reports pointed out that in addition to being an inhibitor of cell proliferation, p21 might protect cells from apoptosis [129]. For example, it has been reported that upregulation of p21 blocked the oxidative stress-induced death of human myeloma U266 cells [130] and rendered resistance to chemotherapy drugs in other types of cancer cells [131]. Thus the increase in $\mathrm{p} 21$ cellular content in $\mathrm{AD}$ may confer these cells a survival advantage. The transcription of $\mathrm{p} 21$ was found to be upregulated in $\mathrm{AD}$ cells by the forkhead box O3a factor (FOXO3a). The reduced ERK1/2 activation of ERK1/2 prevents the phosphorylation of FOX3a and subsequent translocation and degradation via a murine double minute (MDM2)-mediated ubiquitin proteasome pathway, thereby allowing the accumulation of this transcription factor in the nucleus [48]. In addition to the increased transcriptional activation of $p 21$ gene observed in AD lymphoblasts, we also found an increase in the cytosolic content of $\mathrm{p} 21$ protein in $\mathrm{AD}$ cells. The 
cytoplasmic p21 is thought to be a positive modulator of cell survival $[43 ; 132]$. Upregulation of p21 has also been associated with blockade of oxidative stress induced apoptosis in fibroblasts from AD patients [133].

Impairment of mechanisms involved in cell death was previously reported in peripheral cells from AD patients $[120 ; 133-135]$ although there are conflicting results as to whether cells from AD patients are less or more vulnerable to situations that promote cell death. Most likely these discrepancies result from the different cell types and stressinducing conditions used. For example, in contrast with lower sensitivity to serum deprivation-induced death in $\mathrm{AD}$ lymphocytes, these cells appears to be more susceptible to oxidative stress-induced apoptosis [136-138]. The impaired apoptosis mediated by oxidative stress was even observed in MCI patients [137], although enhanced susceptibility to $\mathrm{H}_{2} \mathrm{O}_{2}$-induced death in peripheral lymphocytes correlates with dementia severity and enhanced death in $\mathrm{AD}$ patients is attributable to a Poly (ADP-ribosyl) polymerase-1 (PARP)-dependent increase in the apoptosis/necrosis ratio [138].

The other two important branches besides ERK1/2 of the Mitogen-activated protein kinases (MAPK) signaling, p38 and the c-Jun-N-terminal kinase (JNK), have also been associated to neuronal apoptosis in AD brain [130]. Impaired regulation of expression and activity of these two kinases have been documented in brain and cell models of AD $[139 ; 140]$, and it has been reported that pharmacological modulation of $\mathrm{p} 38 / \mathrm{JNK}$ activity attenuated neuronal cell death [141]. Recent work has reported that both phosphorylated p38 and phosphorylated JNK levels were significantly increased in lymphocytes from AD patients compared with healthy controls, in agreement with the increased expression of phosphorylated p38 and phosphorylated JNK in AD brains [142]. These authors found that phosphorylated p38 and JNK levels in AD lymphocytes 
were positively correlated with disease duration and severity, suggesting the peripheral alteration of these two kinases is more a consequence of a CNS disease mechanism rather than being linked to casual mechanisms. It was suggested that determination of peripheral changes in the expression of the p38 and JNK could provide useful biomarkers of disease progression.

\section{Systemic alterations in mitochondrial dysfunction and in the proteasome activity}

Mitochondrial dysfunction and impairment of the ubiquitin-proteasome system (UPS) are important features of AD shared by the CNS and peripheral cells $[143 ; 144]$. Mitochondria are the main source of energy and the primary source of reactive oxygen species (ROS). Therefore, impairment of mitochondrial function leads to decreased energetic and increased production of free radicals that can in turn have an impact on cellular functions with consequent neuronal loss. On the other hand, dysfunction of the UPS has been associated with the deposition of ubiquitinated protein aggregates [143] and widespread disruption of the proteostasis network. The UPS provides $80 \%$ to $90 \%$ of the proteolysis of the short-life proteins and ensures, as chaperon-molecules, the right conformation and hence the correct function of the proteins [145].

Mitochondrial dysfunction has been documented in peripheral cells from AD patients. For example, it has been reported alterations in the electron transport chain activity in lymphocytes from AD patients [146]. Another study showed decreased mitochondrial membrane potential in $\mathrm{AD}$ lymphocytes, together with a reduced rate of respiration and a significant impairment of total oxidative phosphorylation (OXPHOS) capacity, suggesting mitochondrial uncoupling that led to a failure in the maintenance of cellular energetics [147].

Increased oxidative stress has been also described in lymphocytes from AD patients. The leakage of ROS from mitochondria can be detected by different parameters such as 
the direct measurement of ROS levels, the antioxidant status or DNA oxidation. Many authors have found elevated levels of oxidative DNA damage and increased ROS levels in peripheral lymphocytes $[59 ; 135 ; 148-151]$ that in some cases were also present in MCI patients, suggesting that oxidative stress may represent an early event in the pathogenesis of $\mathrm{AD}$. One of these studies also pointed out the correlation of the higher levels of oxidative DNA damage in peripheral lymphocytes with lower plasma levels of antioxidants [150]. Lower plasma antioxidants have been also described by other groups [152-154], together with lower levels of glutathione in lymphocytes of patients with familial AD [155].

Increased lipid and protein oxidative damage have also been found in mitochondria isolated from patients with $\mathrm{AD}$ [156]. These results were in agreement with the increased lipid peroxidation products found in lymphocytes from patients with the familial form of $\mathrm{AD}$, carrying mutations in amyloid protein precursor $(A P P)$ or presinilin 1 (PS1) genes [157] and in the PS1M146L transgenic mice model of AD [158]. In addition, a recent study pointed out the increased susceptibility of AD lymphoblasts to cell death induced by $\mathrm{H}_{2} \mathrm{O}_{2}$ compared to healthy controls [136].

Several studies in AD lymphocytes have suggested the involvement of p53 signaling in the pathogenesis of $\mathrm{AD}$, due to its role in the response to DNA damage and in cell cycle control $[40 ; 52 ; 159 ; 160]$. Buizza and coworkers found that oxidative imbalance altered the conformation of $\mathrm{p} 53$ protein in lymphocytes from AD patients. They suggested that the oxidation of the p53 could make the protein dysfunctional and represent an early marker of oxidative alterations [161].

It is worth to highlight that lymphocytes from $\mathrm{AD}$ patients represent a useful tool to test the effect of mitochondrial-related therapeutic approaches for AD. The cholinesterase inhibitor rivastigmine, already in use for $\mathrm{AD}$, has been shown to enhance the 
mitochondrial electron transport chain in lymphocytes from AD patients [162], and galantamine or melatonin treatments appear to protect $\mathrm{AD}$ lymphocytes from cell oxidative damage $[163 ; 164]$. In addition, peripheral measures of mitochondrial dysfunction might be helpful in developing biomarkers to combat AD [165; 166].

Alterations in the UPS activity in the CNS and peripheral cells from AD patients might also have detrimental consequences for cell survival $[167 ; 168]$. In the AD brain changes in the UPS have been linked to the accumulation of neurofibrillary tangles [169], and it has been reported that ubiquitin mediates $\mathrm{A} \beta$ neurotoxicity-inducing apoptosis [170].

Changes in the proteasome activity have been observed in peripheral tissues including increased levels of ubiquitin in cerebrospinal fluid (CSF) of AD patients [171] and a reduction in proteasome activity in CD45 T-lymphocytes from the elderly [172]. Work in our laboratory demonstrated selective impaired degradation in the UPS of key proteins involved in the $\mathrm{Ca}^{2+} / \mathrm{CaM}$-dependent regulation of survival/death of lymphoblasts from $\mathrm{AD}$ patients. First, we found that CaM itself is degraded at a lower rate in $\mathrm{AD}$ lymphoblasts than in control cells, allowing the accumulation of the protein in $\mathrm{AD}$ cells [59]. The impaired CaM degradation in $\mathrm{AD}$ lymphoblasts was associated with higher basal ROS levels when compared with control cells. Treatment of lymphoblasts with antioxidants like glutathione $(\mathrm{GSH})$ or trolox reduced ROS levels and restored CaM degradation rate [59]. By contrast, the UPS-dependent degradation of the CDK inhibitors p27 and p21 is enhanced in AD cells [53;173]. The altered rate of degradation of these proteins does not appear to be the result of nonspecific alteration of general protein degradation in lymphoblasts from $\mathrm{AD}$ cells in consonance with reports from other groups $[174 ; 175]$. Nevertheless, the ubiquitin-protein ligase system seems to be affected in PBMCs from AD patients, although they don't show significant 
reduction in global proteasome activity [175]. It was proposed that the determination of two of these ubiquitin-ligases, E1 and E2, in combination with other blood-cell markers may be useful as biomarkers for AD diagnosis [175].

The activation of the NF- $\kappa \mathrm{B}$ transcription factor depends on the degradation in the UPS of the associated inhibitory molecule of the I $\mathrm{B}$ family [176]. Besides its widely known role in inflammation and immune responses, NF- $\kappa \mathrm{B}$ is involved in the control of cell division and apoptosis $[177 ; 178]$. Postmortem brain tissues from AD patients have

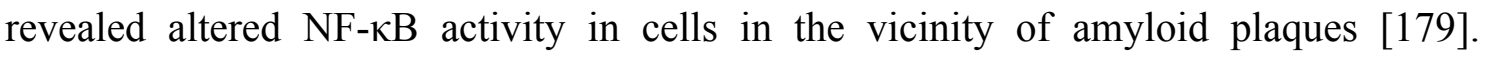
Moreover, it has been shown that conditioned medium from A $\beta$-stimulated glial cells triggers neuronal cell division [180], suggesting that the inflammatory process may be one of the mitotic pressures in AD. Deregulated NF- $\kappa B$ activity has been reported in PBMCs and lymphoblasts from AD patients associated with changes in cell survival $[50 ; 51]$. On the other hand, enhanced UPS-dependent degradation of I $\mathrm{B}$ appears to underlie the beneficial effects of anti-inflammatory molecules in AD [181].

\section{Role of altered lymphocytes response in $\mathrm{AD}$ pathogenesis}

Apart from the molecular alterations observed in lymphocytes derived from AD patients in relation to the mechanisms involved in the control of cell survival/death described above, a large body of evidence indicates the existence of other alterations in systemic immune responses in $\mathrm{AD}$. Changes in lymphocyte and macrophage distribution together with the presence of autoantibodies, inflammatory factors and cytokine production have been described in AD patients [8; 9; 182-189]. Moreover increased expression of Tolllike receptor 2 and 4 (TLR2, TLR4) have been found on PBMCs from AD patients [190]. It is believed that both TLRs are involved in neuroinflammation, due to their ability to bind amyloid- $\beta$ [191]. In addition, global approaches such as microarray analysis of PBMCs and lymphocytes from $\mathrm{AD}$ patients show a prominent gene 
deregulation when compared to age-matched controls $[16 ; 17]$. Changes in patterns of immune mediators in the periphery have been linked to AD and were used to predict disease progression [192].

However, despite the evidence for the existence of a communication between the CNS and the immune system, the involvement of immune alteration in the instigation and/or progression of $\mathrm{AD}$ is far from being completely understood.

Functional integrity of the immune system has been linked to the functional integrity of the brain [193]. It was shown for example that immunocompromised mice display impaired hippocampal functions [194], and the cognitive alterations associated with the immune deficiencies could be rescued by immunomodulation $[195 ; 196]$. On the other hand, it was reported that, the triple-transgenic mouse (3xTg-AD), show premature immunosenescence [197]. 3xTg-AD mouse, which harbors APPSwe and tauP301L transgenes on a mutant Long-chain ceramide is elevated in presenilin 1 (PS1M146V) knock-in background, develops both $\mathrm{A} \beta$ plaques and neurofibrillary tangles with a temporal- and regional-specific profile that closely mimics their development in the human AD brain [198]. Taken together, these studies suggest that circulating immune cells play an essential role in brain function and support the involvement of systemic immunity and inflammation in behavioral and cognitive deficits, such as those in AD. In other words, the immune cells present in the CNS may have neuroprotective effects. However, accumulation of immune cells in brain areas or uncontrolled cell response could eventually increase the oxidative and inflammatory processes and contribute to the instigation or progression of neurodegeneration [199]. Apparently acute activation of the circulating immune cells within the CNS has different consequences for the young and aged/or diseased brain. In the latter conditions, systemic inflammation 
impacts on resident microglia to adopt a more aggressive phenotype with the enhanced synthesis of pro-inflammatory mediators.

On the other hand, abnormalities found in circulating immune cells could be the downstream result of $\mathrm{AD}$ processes leading to a deficient control of peripheral processes. The brain regulates key biological processes throughout the organism by releasing molecules into the blood and CSF. Proteins, such as amyloid- $\beta$, or inflammatory mediators from the CNS may cause systemic immune reaction. Therefore, communication between the CNS and the immune system in AD could thus influence both the lymphocyte distribution in the blood and the production of immune mediators $[15 ; 200]$. PBMCs from AD patients show increased production of several cytokines, chemokines, as well as increased expression of growth factors and chemokine receptors, after in vitro stimulation by $A \beta$ [188]. Amyloid- $\beta$ was reported to stimulate the proliferative response of lymphocytes from AD patients [201]. Cytokines, chemokines, and growth factors regulate diverse cellular processes, including proliferation and survival, and they are important for the development and function of the hematopoietic and nervous systems. In Fig. 1 we have summarized schematically the bidirectional communication between the CNS and the immune system, highlighting the reported changes in lymphocytes signaling.

The possibility should also be considered that both changes in the CNS and systemic alterations share common underlying etiological processes. AD has been proposed to be a multifactorial disease that affects both CNS and systemic processes [202]. Most likely, there is no a single trigger that could explain AD etiology, but several interconnected processes, that together with genetic risk factors, determine the clinical manifestations of dementia. 


\section{Concluding Remarks}

The studies summarized here suggest that $\mathrm{AD}$ is accompanied by changes in peripheral cells, particularly those in the immune system. Changes that occur in lymphocytes from AD subjects include cell cycle deregulation, alterations in cell viability, proliferation, apoptosis, oxidative metabolism, proteasome activity, calcium homeostasis, and cellular signal transduction systems. At present it is not possible to conclude whether immune changes play a significant role in the development of cognitive decline, or by contrast they are downstream consequence of brain pathology. Nonetheless, evaluation of systemic alterations may be useful to further characterize immune dysfunction during disease progression, and their influence on AD pathology. On the other hand, because of their easy accessibility, peripheral cells may be of great importance for identification of biological markers of $\mathrm{AD}$, and a suitable platform for monitoring the efficiency of novel therapies.

\section{Acknowledgements}

Work in the author's laboratory is supported by grants from the Spanish Ministry of Ministry of Economy and Competiveness (SAF2011-28603) and Fundación Ramón Areces. We would like to thank Dr. M. S. Ayuso for her constructive feedback on the manuscript. We are grateful to former members of the group, especially Drs. $\mathrm{N}$ de las Cuevas, F. Bartolomé and U. Muñoz.

\section{Conflict of Interest Statement}

The authors declare that they have no conflict of interest 


\section{References}

[1] Hebert LE, Weuve J, Scherr PA, Evans DA. Alzheimer disease in the United States (2010-2050) estimated using the 2010 census. Neurology 80(19): 1778-83.(2013).

[2] Stoeck K, Schmitz M, Ebert E, Schmidt C, Zerr I. Immune responses in rapidly progressive dementia: a comparative study of neuroinflammatory markers in Creutzfeldt-Jakob disease, Alzheimer inverted question marks disease and multiple sclerosis. Journal of neuroinflammation 11(1): 170.(2014).

[3] Akiyama H, Barger S, Barnum S, Bradt B, Bauer J, Cole GM, et al. Inflammation and Alzheimer's disease. Neurobiol Aging 21(3): 383-421.(2000).

[4] Wyss-Coray T. Inflammation in Alzheimer disease: driving force, bystander or beneficial response? Nature medicine 12(9): 1005-15.(2006).

[5] Rubio-Perez JM, Morillas-Ruiz JM. A review: inflammatory process in Alzheimer's disease, role of cytokines. TheScientificWorldJournal 2012: 756357.(2012).

[6] Bonotis K, Krikki E, Holeva V, Aggouridaki C, Costa V, Baloyannis S. Systemic immune aberrations in Alzheimer's disease patients. Journal of neuroimmunology 193(1-2): 183-7.(2008).

[7] Lombardi VR, Garcia M, Rey L, Cacabelos R. Characterization of cytokine production, screening of lymphocyte subset patterns and in vitro apoptosis in healthy and Alzheimer's Disease (AD) individuals. Journal of neuroimmunology 97(1-2): 16371.(1999).

[8] Pellicano M, Larbi A, Goldeck D, Colonna-Romano G, Buffa S, Bulati M, et al. Immune profiling of Alzheimer patients. Journal of neuroimmunology 242(1-2): 529.(2012). 
[9] Speciale L, Calabrese E, Saresella M, Tinelli C, Mariani C, Sanvito L, et al. Lymphocyte subset patterns and cytokine production in Alzheimer's disease patients. Neurobiol Aging 28(8): 1163-9.(2007).

[10] Dantzer R, O'Connor JC, Freund GG, Johnson RW, Kelley KW. From inflammation to sickness and depression: when the immune system subjugates the brain. Nature reviews Neuroscience 9(1): 46-56.(2008).

[11] McColl BW, Allan SM, Rothwell NJ. Systemic infection, inflammation and acute ischemic stroke. Neuroscience 158(3): 1049-61.(2009).

[12] Cunningham C, Campion S, Teeling J, Felton L, Perry VH. The sickness behaviour and CNS inflammatory mediator profile induced by systemic challenge of mice with synthetic double-stranded RNA (poly I:C). Brain, behavior, and immunity 21(4): 490502.(2007).

[13] Lacroix S, Rivest S. Effect of acute systemic inflammatory response and cytokines on the transcription of the genes encoding cyclooxygenase enzymes (COX-1 and COX2) in the rat brain. Journal of neurochemistry 70(2): 452-66.(1998).

[14] Ek M, Engblom D, Saha S, Blomqvist A, Jakobsson PJ, Ericsson-Dahlstrand A. Inflammatory response: pathway across the blood-brain barrier. Nature 410(6827): 4301.(2001).

[15] Britschgi M, Wyss-Coray T. Systemic and acquired immune responses in Alzheimer's disease. International review of neurobiology 82: 205-33.(2007).

[16] Kalman J, Palotas A, Juhasz A, Rimanoczy A, Hugyecz M, Kovacs Z, et al. Impact of venlafaxine on gene expression profile in lymphocytes of the elderly with major depression--evolution of antidepressants and the role of the "neuro-immune" system. Neurochemical research 30(11): 1429-38.(2005). 
[17] Maes OC, Xu S, Yu B, Chertkow HM, Wang E, Schipper HM. Transcriptional profiling of Alzheimer blood mononuclear cells by microarray. Neurobiol Aging 28(12): 1795-809.(2007).

[18] Reale M, Greig NH, Kamal MA. Peripheral chemo-cytokine profiles in Alzheimer's and Parkinson's diseases. Mini reviews in medicinal chemistry 9(10): 122941.(2009).

[19] Percy M, Andrews DF, Potter H. In: Peripheral markers of Alzheimer's disease. (Eds: Scinto LFM, Daffner KR) Early Diagnosis of Alzheimer's Disease. Totowa, NJ: Human Press. pp 191-268.(2000).

[20] Fehlbaum-Beurdeley P, Jarrige-Le Prado AC, Pallares D, Carriere J, Guihal C, Soucaille C, et al. Toward an Alzheimer's disease diagnosis via high-resolution blood gene expression. Alzheimer's \& dementia : the journal of the Alzheimer's Association 6(1): 25-38.(2010).

[21] Miglio G, Varsaldi F, Lombardi G. Human T lymphocytes express N-methyl-Daspartate receptors functionally active in controlling $\mathrm{T}$ cell activation. Biochemical and biophysical research communications 338(4): 1875-83.(2005).

[22] Buttarelli FR, Fanciulli A, Pellicano C, Pontieri FE. The dopaminergic system in peripheral blood lymphocytes: from physiology to pharmacology and potential applications to neuropsychiatric disorders. Current neuropharmacology 9(2): 27888.(2011).

[23] Skok MV, Kalashnik EN, Koval LN, Tsetlin VI, Utkin YN, Changeux JP, et al. Functional nicotinic acetylcholine receptors are expressed in B lymphocyte-derived cell lines. Molecular pharmacology 64(4): 885-9.(2003).

[24] Nagy Z, Esiri MM, Smith AD. The cell division cycle and the pathophysiology of Alzheimer's disease. Neuroscience 87(4): 731-9.(1998). 
[25] Raina AK, Zhu X, Smith MA. Alzheimer's disease and the cell cycle. Acta neurobiologiae experimentalis 64(1): 107-12.(2004).

[26] Vincent I, Rosado M, Davies P. Mitotic mechanisms in Alzheimer's disease? The Journal of cell biology 132(3): 413-25.(1996).

[27] Yang Y, Herrup K. Cell division in the CNS: protective response or lethal event in post-mitotic neurons? Biochim Biophys Acta 1772(4): 457-66.(2007).

[28] Bonda DJ, Bajic VP, Spremo-Potparevic B, Casadesus G, Zhu X, Smith MA, et al. Review: cell cycle aberrations and neurodegeneration. Neuropathology and applied neurobiology 36(2): 157-63.(2010).

[29] Lee HG, Casadesus G, Zhu X, Castellani RJ, McShea A, Perry G, et al. Cell cycle re-entry mediated neurodegeneration and its treatment role in the pathogenesis of Alzheimer's disease. Neurochemistry international 54(2): 84-8.(2009).

[30] Arendt T. Synaptic plasticity and cell cycle activation in neurons are alternative effector pathways: the 'Dr. Jekyll and Mr. Hyde concept' of Alzheimer's disease or the yin and yang of neuroplasticity. Progress in neurobiology 71(2-3): 83-248.(2003).

[31] McShea A, Harris PL, Webster KR, Wahl AF, Smith MA. Abnormal expression of the cell cycle regulators P16 and CDK4 in Alzheimer's disease. The American journal of pathology 150(6): 1933-9.(1997).

[32] Kook SY, Seok Hong H, Moon M, Mook-Jung I. Disruption of blood-brain barrier in Alzheimer disease pathogenesis. Tissue barriers 1(2): e23993.(2013).

[33] Bialopiotrowicz E, Kuzniewska B, Kachamakova-Trojanowska N, Barcikowska M, Kuznicki J, Wojda U. Cell cycle regulation distinguishes lymphocytes from sporadic and familial Alzheimer's disease patients. Neurobiol Aging 32(12): 2319.e13-26.(2011). [34] de las Cuevas N, Urcelay E, Hermida OG, Saiz-Diaz RA, Bermejo F, Ayuso MS, et al. $\mathrm{Ca} 2+/$ calmodulin-dependent modulation of cell cycle elements $\mathrm{pRb}$ and $\mathrm{p} 27 \mathrm{kip} 1$ 
involved in the enhanced proliferation of lymphoblasts from patients with Alzheimer dementia. Neurobiology of disease 13(3): 254-63.(2003).

[35] Nagy Z, Combrinck M, Budge M, McShane R. Cell cycle kinesis in lymphocytes in the diagnosis of Alzheimer's disease. Neurosci Lett 317(2): 81-4.(2002).

[36] Stieler J, Grimes R, Weber D, Gartner W, Sabbagh M, Arendt T. Multivariate analysis of differential lymphocyte cell cycle activity in Alzheimer's disease. Neurobiol Aging 33(2): 234-41.(2012).

[37] Tatebayashi Y, Takeda M, Kashiwagi Y, Okochi M, Kurumadani T, Sekiyama A, et al. Cell-cycle-dependent abnormal calcium response in fibroblasts from patients with familial Alzheimer's disease. Dementia (Basel, Switzerland) 6(1): 9-16.(1995).

[38] Zhou X, Jia J. P53-mediated G(1)/S checkpoint dysfunction in lymphocytes from Alzheimer's disease patients. Neurosci Lett 468(3): 320-5.(2010).

[39] Song J, Wang S, Tan M, Jia J. G1/S checkpoint proteins in peripheral blood lymphocytes are potentially diagnostic biomarkers for Alzheimer's disease. Neurosci Lett 526(2): 144-9.(2012).

[40] Bialopiotrowicz E, Szybinska A, Kuzniewska B, Buizza L, Uberti D, Kuznicki J, et al. Highly pathogenic Alzheimer's disease presenilin $1 \mathrm{P} 117 \mathrm{R}$ mutation causes a specific increase in p53 and p21 protein levels and cell cycle dysregulation in human lymphocytes. J Alzheimers Dis 32(2): 397-415.(2012).

[41] Lundberg AS, Weinberg RA. Functional inactivation of the retinoblastoma protein requires sequential modification by at least two distinct cyclin-cdk complexes. Molecular and cellular biology 18(2): 753-61.(1998).

[42] Zhang J, Li H, Yabut O, Fitzpatrick H, D'Arcangelo G, Herrup K. Cdk5 suppresses the neuronal cell cycle by disrupting the E2F1-DP1 complex. The Journal of 
neuroscience : the official journal of the Society for Neuroscience 30(15): 521928.(2010).

[43] Coqueret O. New roles for p21 and p27 cell-cycle inhibitors: a function for each cell compartment? Trends in cell biology 13(2): 65-70.(2003).

[44] Arendt T. Alzheimer's disease as a disorder of mechanisms underlying structural brain self-organization. Neuroscience 102(4): 723-65.(2001).

[45] Ranganathan S, Scudiere S, Bowser R. Hyperphosphorylation of the retinoblastoma gene product and altered subcellular distribution of E2F-1 during Alzheimer's disease and amyotrophic lateral sclerosis. J Alzheimers Dis 3(4): 37785.(2001).

[46] Stone JG, Siedlak SL, Tabaton M, Hirano A, Castellani RJ, Santocanale C, et al. The cell cycle regulator phosphorylated retinoblastoma protein is associated with tau pathology in several tauopathies. Journal of neuropathology and experimental neurology 70(7): 578-87.(2011).

[47] Jordan-Sciutto K, Rhodes J, Bowser R. Altered subcellular distribution of transcriptional regulators in response to Abeta peptide and during Alzheimer's disease. Mechanisms of ageing and development 123(1): 11-20.(2001).

[48] Esteras N, Alquezar C, Bermejo-Pareja F, Bialopiotrowicz E, Wojda U, MartinRequero A. Downregulation of extracellular signal-regulated kinase $1 / 2$ activity by calmodulin KII modulates p21Cip1 levels and survival of immortalized lymphocytes from Alzheimer's disease patients. Neurobiol Aging 34(4): 1090-100.(2013).

[49] Munoz U, de Las Cuevas N, Bartolome F, Hermida OG, Bermejo F, MartinRequero A. The cyclopentenone 15-deoxy-delta(12,14)-prostaglandin J2 inhibits G1/S transition and retinoblastoma protein phosphorylation in immortalized lymphocytes from Alzheimer's disease patients. Experimental neurology 195(2): 508-17.(2005). 
[50] de las Cuevas N, Munoz U, Hermida OG, Martin-Requero A. Altered transcriptional regulators in response to serum in immortalized lymphocytes from Alzheimer's disease patients. Neurobiol Aging 26(5): 615-24.(2005).

[51] Ascolani A, Balestrieri E, Minutolo A, Mosti S, Spalletta G, Bramanti P, et al. Dysregulated NF-kappaB pathway in peripheral mononuclear cells of Alzheimer's disease patients. Curr Alzheimer Res 9(1): 128-37.(2012).

[52] Dezor M, Dorszewska J, Florczak J, Kempisty B, Jaroszewska-Kolecka J, Rozycka A, et al. Expression of 8-oxoguanine DNA glycosylase 1 (OGG1) and the level of p53 and TNF-alphalpha proteins in peripheral lymphocytes of patients with Alzheimer's disease. Folia Neuropathol 49(2): 123-31.(2011).

[53] Munoz U, Bartolome F, Bermejo F, Martin-Requero A. Enhanced proteasomedependent degradation of the CDK inhibitor p27(kip1) in immortalized lymphocytes from Alzheimer's dementia patients. Neurobiol Aging 29(10): 1474-84.(2008).

[54] Urcelay E, Ibarreta D, Parrilla R, Ayuso MS, Martin-Requero A. Enhanced proliferation of lymphoblasts from patients with Alzheimer dementia associated with calmodulin-dependent activation of the na $+\mathrm{H}+$ exchanger. Neurobiology of disease 8(2): 289-98.(2001).

[55] Liang J, Zubovitz J, Petrocelli T, Kotchetkov R, Connor MK, Han K, et al. $\mathrm{PKB} /$ Akt phosphorylates p27, impairs nuclear import of p27 and opposes p27-mediated G1 arrest. Nature medicine 8(10): 1153-60.(2002).

[56] Munoz U, Bartolome F, Esteras N, Bermejo-Pareja F, Martin-Requero A. On the mechanism of inhibition of p27 degradation by 15-deoxy-Delta12,14-prostaglandin J2 in lymphoblasts of Alzheimer's disease patients. Cellular and molecular life sciences : CMLS 65(21): 3507-19.(2008). 
[57] Griffin RJ, Moloney A, Kelliher M, Johnston JA, Ravid R, Dockery P, et al. Activation of $\mathrm{Akt} / \mathrm{PKB}$, increased phosphorylation of Akt substrates and loss and altered distribution of Akt and PTEN are features of Alzheimer's disease pathology. Journal of neurochemistry 93(1): 105-17.(2005).

[58] Oddo S. The role of mTOR signaling in Alzheimer disease. Frontiers in bioscience (Scholar edition) 4: 941-52.(2012).

[59] Esteras N, Munoz U, Alquezar C, Bartolome F, Bermejo-Pareja F, Martin-Requero A. Altered calmodulin degradation and signaling in non-neuronal cells from Alzheimer's disease patients. Curr Alzheimer Res 9(3): 267-77.(2012).

[60] Joyal JL, Burks DJ, Pons S, Matter WF, Vlahos CJ, White MF, et al. Calmodulin activates phosphatidylinositol 3-kinase. The Journal of biological chemistry 272(45): 28183-6.(1997).

[61] Perez-Garcia MJ, Cena V, de Pablo Y, Llovera M, Comella JX, Soler RM. Glial cell line-derived neurotrophic factor increases intracellular calcium concentration. Role of calcium/calmodulin in the activation of the phosphatidylinositol 3-kinase pathway. The Journal of biological chemistry 279(7): 6132-42.(2004).

[62] Bojarski L, Pomorski P, Szybinska A, Drab M, Skibinska-Kijek A, GruszczynskaBiegala J, et al. Presenilin-dependent expression of STIM proteins and dysregulation of capacitative $\mathrm{Ca} 2+$ entry in familial Alzheimer's disease. Biochim Biophys Acta 1793(6): 1050-7.(2009).

[63] Eckert A, Forstl H, Zerfass R, Hennerici M, Muller WE. Free intracellular calcium in peripheral cells in Alzheimer's disease. Neurobiol Aging 18(3): 281-4.(1997).

[64] Ibarreta D, Parrilla R, Ayuso MS. Altered Ca2+ homeostasis in lymphoblasts from patients with late-onset Alzheimer disease. Alzheimer disease and associated disorders 11(4): 220-7.(1997). 
[65] Jaworska A, Dzbek J, Styczynska M, Kuznicki J. Analysis of calcium homeostasis in fresh lymphocytes from patients with sporadic Alzheimer's disease or mild cognitive impairment. Biochim Biophys Acta 1833(7): 1692-9.(2013).

[66] Sulger J, Dumais-Huber C, Zerfass R, Henn FA, Aldenhoff JB. The calcium response of human $\mathrm{T}$ lymphocytes is decreased in aging but increased in Alzheimer's dementia. Biological psychiatry 45(6): 737-42.(1999).

[67] Bojarski L, Herms J, Kuznicki J. Calcium dysregulation in Alzheimer's disease. Neurochemistry international 52(4-5): 621-33.(2008).

[68] Gibson GE, Nielsen P, Sherman KA, Blass JP. Diminished mitogen-induced calcium uptake by lymphocytes from Alzheimer patients. Biological psychiatry 22(9): 1079-86.(1987).

[69] Fowler CJ, Cowburn RF, Garlind A, Winblad B, O'Neill C. Disturbances in signal transduction mechanisms in Alzheimer's disease. Molecular and cellular biochemistry 149-150: 287-92.(1995).

[70] Ciccocioppo F, Lanuti P, Marchisio M, Gambi F, Santavenere E, Pierdomenico L, et al. Expression and phosphorylation of protein kinase C isoforms in Abeta(1-42) activated $\mathrm{T}$ lymphocytes from Alzheimers disease. International journal of immunopathology and pharmacology 21(1): 23-33.(2008).

[71] Saitoh T, Horsburgh K, Masliah E. Hyperactivation of signal transduction systems in Alzheimer's disease. Annals of the New York Academy of Sciences 695: 3441.(1993).

[72] Cheung KH, Mei L, Mak DO, Hayashi I, Iwatsubo T, Kang DE, et al. Gain-offunction enhancement of IP3 receptor modal gating by familial Alzheimer's diseaselinked presenilin mutants in human cells and mouse neurons. Science signaling 3(114): ra22.(2010). 
[73] Hye A, Kerr F, Archer N, Foy C, Poppe M, Brown R, et al. Glycogen synthase kinase-3 is increased in white cells early in Alzheimer's disease. Neurosci Lett 373(1): 1-4.(2005).

[74] Lafay-Chebassier C, Paccalin M, Page G, Barc-Pain S, Perault-Pochat MC, Gil R, et al. mTOR/p70S6k signalling alteration by Abeta exposure as well as in APP-PS1 transgenic models and in patients with Alzheimer's disease. Journal of neurochemistry 94(1): 215-25.(2005).

[75] Gibbons JJ, Abraham RT, Yu K. Mammalian target of rapamycin: discovery of rapamycin reveals a signaling pathway important for normal and cancer cell growth. Seminars in oncology 36 Suppl 3: S3-s17.(2009).

[76] Hoeffer CA, Klann E. mTOR signaling: at the crossroads of plasticity, memory and disease. Trends in neurosciences 33(2): 67-75.(2010).

[77] Cai Z, Zhao B, Li K, Zhang L, Li C, Quazi SH, et al. Mammalian target of rapamycin: a valid therapeutic target through the autophagy pathway for Alzheimer's disease? Journal of neuroscience research 90(6): 1105-18.(2012).

[78] Paccalin M, Pain-Barc S, Pluchon C, Paul C, Besson MN, Carret-Rebillat AS, et al. Activated mTOR and PKR kinases in lymphocytes correlate with memory and cognitive decline in Alzheimer's disease. Dementia and geriatric cognitive disorders 22(4): 320-6.(2006).

[79] Yates SC, Zafar A, Hubbard P, Nagy S, Durant S, Bicknell R, et al. Dysfunction of the mTOR pathway is a risk factor for Alzheimer's disease. Acta neuropathologica communications 1(1): 3.(2013).

[80] Jope RS, Yuskaitis CJ, Beurel E. Glycogen synthase kinase-3 (GSK3): inflammation, diseases, and therapeutics. Neurochemical research 32(4-5): 57795.(2007). 
[81] Muyllaert D, Kremer A, Jaworski T, Borghgraef P, Devijver H, Croes S, et al. Glycogen synthase kinase-3beta, or a link between amyloid and tau pathology? Genes, brain, and behavior 7 Suppl 1: 57-66.(2008).

[82] Peineau S, Bradley C, Taghibiglou C, Doherty A, Bortolotto ZA, Wang YT, et al. The role of GSK-3 in synaptic plasticity. British journal of pharmacology 153 Suppl 1: S428-37.(2008).

[83] Lovestone S, Reynolds CH, Latimer D, Davis DR, Anderton BH, Gallo JM, et al. Alzheimer's disease-like phosphorylation of the microtubule-associated protein tau by glycogen synthase kinase-3 in transfected mammalian cells. Current biology : CB 4(12): 1077-86.(1994).

[84] Rockenstein E, Torrance M, Adame A, Mante M, Bar-on P, Rose JB, et al. Neuroprotective effects of regulators of the glycogen synthase kinase-3beta signaling pathway in a transgenic model of Alzheimer's disease are associated with reduced amyloid precursor protein phosphorylation. The Journal of neuroscience : the official journal of the Society for Neuroscience 27(8): 1981-91.(2007).

[85] Grimes CA, Jope RS. The multifaceted roles of glycogen synthase kinase 3beta in cellular signaling. Progress in neurobiology 65(4): 391-426.(2001).

[86] Lucas JJ, Hernandez F, Gomez-Ramos P, Moran MA, Hen R, Avila J. Decreased nuclear beta-catenin, tau hyperphosphorylation and neurodegeneration in GSK-3beta conditional transgenic mice. The EMBO journal 20(1-2): 27-39.(2001).

[87] Forlenza OV, Torres CA, Talib LL, de Paula VJ, Joaquim HP, Diniz BS, et al. Increased platelet GSK3B activity in patients with mild cognitive impairment and Alzheimer's disease. Journal of psychiatric research 45(2): 220-4.(2011).

[88] Doble BW, Woodgett JR. GSK-3: tricks of the trade for a multi-tasking kinase. Journal of cell science 116(Pt 7): 1175-86.(2003). 
[89] de la Monte SM, Tong M, Lester-Coll N, Plater M, Jr., Wands JR. Therapeutic rescue of neurodegeneration in experimental type 3 diabetes: relevance to Alzheimer's disease. J Alzheimers Dis 10(1): 89-109.(2006).

[90] Dineley KT, Jahrling JB, Denner L. Insulin resistance in Alzheimer's disease. Neurobiology of disease2014).

[91] Messier C, Teutenberg K. The role of insulin, insulin growth factor, and insulindegrading enzyme in brain aging and Alzheimer's disease. Neural plasticity 12(4): 31128.(2005).

[92] Hoyer S. Causes and consequences of disturbances of cerebral glucose metabolism in sporadic Alzheimer disease: therapeutic implications. Advances in experimental medicine and biology 541: 135-52.(2004).

[93] Bondy CA, Cheng CM. Signaling by insulin-like growth factor 1 in brain. European journal of pharmacology 490(1-3): 25-31.(2004).

[94] Lee HK, Kumar P, Fu Q, Rosen KM, Querfurth HW. The insulin/Akt signaling pathway is targeted by intracellular beta-amyloid. Molecular biology of the cell 20(5): 1533-44.(2009).

[95] Craft S, Baker LD, Montine TJ, Minoshima S, Watson GS, Claxton A, et al. Intranasal insulin therapy for Alzheimer disease and amnestic mild cognitive impairment: a pilot clinical trial. Arch Neurol 69(1): 29-38.(2012).

[96] Park CR, Seeley RJ, Craft S, Woods SC. Intracerebroventricular insulin enhances memory in a passive-avoidance task. Physiology \& behavior 68(4): 509-14.(2000).

[97] Watson GS, Baker LD, Cholerton BA, Rhoads KW, Merriam GR, Schellenberg GD, et al. Effects of insulin and octreotide on memory and growth hormone in Alzheimer's disease. J Alzheimers Dis 18(3): 595-602.(2009). 
[98] Jimenez-Palomares M, Ramos-Rodriguez JJ, Lopez-Acosta JF, Pacheco-Herrero M, Lechuga-Sancho AM, Perdomo G, et al. Increased Abeta production prompts the onset of glucose intolerance and insulin resistance. American journal of physiology Endocrinology and metabolism 302(11): E1373-80.(2012).

[99] Castri P, Iacovelli L, De Blasi A, Giubilei F, Moretti A, Tari Capone F, et al. Reduced insulin-induced phosphatidylinositol-3-kinase activation in peripheral blood mononuclear leucocytes from patients with Alzheimer's disease. The European journal of neuroscience 26(9): 2469-72.(2007).

[100] Wu G, He X. Threonine 41 in beta-catenin serves as a key phosphorylation relay residue in beta-catenin degradation. Biochemistry 45(16): 5319-23.(2006).

[101] Barker N, Morin PJ, Clevers H. The Yin-Yang of TCF/beta-catenin signaling. Advances in cancer research 77: 1-24.(2000).

[102] Willert K, Nusse R. Beta-catenin: a key mediator of Wnt signaling. Current opinion in genetics \& development 8(1): 95-102.(1998).

[103] Martin M, Rehani K, Jope RS, Michalek SM. Toll-like receptor-mediated cytokine production is differentially regulated by glycogen synthase kinase 3 . Nature immunology 6(8): 777-84.(2005).

[104] Llorens-Martin M, Jurado J, Hernandez F, Avila J. GSK-3beta, a pivotal kinase in Alzheimer disease. Frontiers in molecular neuroscience 7: 46.(2014).

[105] Inestrosa NC, Varela-Nallar L. Wnt signaling in the nervous system and in Alzheimer's disease. Journal of molecular cell biology 6(1): 64-74.(2014).

[106] Inestrosa N, De Ferrari GV, Garrido JL, Alvarez A, Olivares GH, Barria MI, et al. Wnt signaling involvement in beta-amyloid-dependent neurodegeneration. Neurochemistry international 41(5): 341-4.(2002). 
[107] Caricasole A, Bakker A, Copani A, Nicoletti F, Gaviraghi G, Terstappen GC. Two sides of the same coin: Wnt signaling in neurodegeneration and neuro-oncology. Bioscience reports 25(5-6): 309-27.(2005).

[108] Guo Q, Fu W, Xie J, Luo H, Sells SF, Geddes JW, et al. Par-4 is a mediator of neuronal degeneration associated with the pathogenesis of Alzheimer disease. Nature medicine 4(8): 957-62.(1998).

[109] Adamec E, Vonsattel JP, Nixon RA. DNA strand breaks in Alzheimer's disease. Brain research 849(1-2): 67-77.(1999).

[110] Anderson AJ, Stoltzner S, Lai F, Su J, Nixon RA. Morphological and biochemical assessment of DNA damage and apoptosis in Down syndrome and Alzheimer disease, and effect of postmortem tissue archival on TUNEL. Neurobiol Aging 21(4): 51124.(2000).

[111] Bonda DJ, Evans TA, Santocanale C, Llosa JC, Vina J, Bajic V, et al. Evidence for the progression through S-phase in the ectopic cell cycle re-entry of neurons in Alzheimer disease. Aging 1(4): 382-8.(2009).

[112] Yang Y, Geldmacher DS, Herrup K. DNA replication precedes neuronal cell death in Alzheimer's disease. The Journal of neuroscience : the official journal of the Society for Neuroscience 21(8): 2661-8.(2001).

[113] Currais A, Hortobagyi T, Soriano S. The neuronal cell cycle as a mechanism of pathogenesis in Alzheimer's disease. Aging 1(4): 363-71.(2009).

[114] Raina AK, Hochman A, Zhu X, Rottkamp CA, Nunomura A, Siedlak SL, et al. Abortive apoptosis in Alzheimer's disease. Acta neuropathologica 101(4): 30510.(2001).

[115] Jellinger KA. Cell death mechanisms in neurodegeneration. J Cell Mol Med 5(1): 1-17.(2001). 
[116] Zhu X, Lee HG, Perry G, Smith MA. Alzheimer disease, the two-hit hypothesis: an update. Biochim Biophys Acta 1772(4): 494-502.(2007).

[117] Zhu X, Raina AK, Perry G, Smith MA. Alzheimer's disease: the two-hit hypothesis. The Lancet Neurology 3(4): 219-26.(2004).

[118] Perry G, Zhu X, Smith MA. Do neurons have a choice in death? The American journal of pathology 158(1): 1-2.(2001).

[119] Bartolome F, de Las Cuevas N, Munoz U, Bermejo F, Martin-Requero A. Impaired apoptosis in lymphoblasts from Alzheimer's disease patients: cross-talk of $\mathrm{Ca} 2+/$ calmodulin and ERK1/2 signaling pathways. Cellular and molecular life sciences : CMLS 64(11): 1437-48.(2007).

[120] Uberti D, Carsana T, Bernardi E, Rodella L, Grigolato P, Lanni C, et al. Selective impairment of p53-mediated cell death in fibroblasts from sporadic Alzheimer's disease patients. Journal of cell science 115(Pt 15): 3131-8.(2002).

[121] Bartolome F, Munoz U, Esteras N, Alquezar C, Collado A, Bermejo-Pareja F, et al. Simvastatin overcomes the resistance to serum withdrawal-induced apoptosis of lymphocytes from Alzheimer's disease patients. Cellular and molecular life sciences : CMLS 67(24): 4257-68.(2010).

[122] Grimm S, Bauer MK, Baeuerle PA, Schulze-Osthoff K. Bcl-2 down-regulates the activity of transcription factor NF-kappaB induced upon apoptosis. The Journal of cell biology 134(1): 13-23.(1996).

[123] Nitta T, Chiba A, Yamashita A, Rowe M, Israel A, Reth M, et al. NF-kappaB is required for cell death induction by latent membrane protein 1 of Epstein-Barr virus. Cellular signalling 15(4): 423-33.(2003).

[124] Marshall CJ. Specificity of receptor tyrosine kinase signaling: transient versus sustained extracellular signal-regulated kinase activation. Cell 80(2): 179-85.(1995). 
[125] Pouyssegur J, Volmat V, Lenormand P. Fidelity and spatio-temporal control in MAP kinase (ERKs) signalling. Biochemical pharmacology 64(5-6): 755-63.(2002).

[126] Choi BK, Choi CH, Oh HL, Kim YK. Role of ERK activation in cisplatininduced apoptosis in A172 human glioma cells. Neurotoxicology 25(6): 915-24.(2004). [127] Tang D, Wu D, Hirao A, Lahti JM, Liu L, Mazza B, et al. ERK activation mediates cell cycle arrest and apoptosis after DNA damage independently of $\mathrm{p} 53$. The Journal of biological chemistry 277(15): 12710-7.(2002).

[128] Wang X, Martindale JL, Holbrook NJ. Requirement for ERK activation in cisplatin-induced apoptosis. The Journal of biological chemistry 275(50): 3943543.(2000).

[129] Gartel AL. p21(WAF1/CIP1) and cancer: a shifting paradigm? BioFactors (Oxford, England) 35(2): 161-4.(2009).

[130] Kim DK, Cho ES, Lee SJ, Um HD. Constitutive hyperexpression of p21(WAF1) in human U266 myeloma cells blocks the lethal signaling induced by oxidative stress but not by Fas. Biochemical and biophysical research communications 289(1): 348.(2001).

[131] Gareau C, Fournier MJ, Filion C, Coudert L, Martel D, Labelle Y, et al. p21(WAF1/CIP1) upregulation through the stress granule-associated protein CUGBP1 confers resistance to bortezomib-mediated apoptosis. PLoS One 6(5): e20254.(2011). [132] Blagosklonny MV. Are p27 and p21 cytoplasmic oncoproteins? Cell cycle (Georgetown, Tex) 1(6): 391-3.(2002).

[133] Naderi J, Lopez C, Pandey S. Chronically increased oxidative stress in fibroblasts from Alzheimer's disease patients causes early senescence and renders resistance to apoptosis by oxidative stress. Mechanisms of ageing and development 127(1): 2535.(2006). 
[134] Eckert A, Oster M, Zerfass R, Hennerici M, Muller WE. Elevated levels of fragmented DNA nucleosomes in native and activated lymphocytes indicate an enhanced sensitivity to apoptosis in sporadic Alzheimer's disease. Specific differences to vascular dementia. Dementia and geriatric cognitive disorders 12(2): 98-105.(2001). [135] Morocz M, Kalman J, Juhasz A, Sinko I, McGlynn AP, Downes CS, et al. Elevated levels of oxidative DNA damage in lymphocytes from patients with Alzheimer's disease. Neurobiol Aging 23(1): 47-53.(2002).

[136] Behrens MI, Silva M, Salech F, Ponce DP, Merino D, Sinning M, et al. Inverse susceptibility to oxidative death of lymphocytes obtained from Alzheimer's patients and skin cancer survivors: increased apoptosis in Alzheimer's and reduced necrosis in cancer. J Gerontol A Biol Sci Med Sci 67(10): 1036-40.(2012).

[137] Gatta L, Cardinale A, Wannenes F, Consoli C, Armani A, Molinari F, et al. Peripheral blood mononuclear cells from mild cognitive impairment patients show deregulation of Bax and Sod1 mRNAs. Neurosci Lett 453(1): 36-40.(2009).

[138] Ponce DE, Salech F, Martin CS, Silva ME, Xiong C, Roe CM, et al. Increased Susceptibility to Oxidative Death of Lymphocytes from Alzheimer Patients Correlates with Dementia Severity. Curr Alzheimer Res2014).

[139] Pearson AG, Byrne UT, MacGibbon GA, Faull RL, Dragunow M. Activated cJun is present in neurofibrillary tangles in Alzheimer's disease brains. Neurosci Lett 398(3): 246-50.(2006).

[140] Sun A, Liu M, Nguyen XV, Bing G. P38 MAP kinase is activated at early stages in Alzheimer's disease brain. Experimental neurology 183(2): 394-405.(2003).

[141] Xuan A, Long D, Li J, Ji W, Zhang M, Hong L, et al. Hydrogen sulfide attenuates spatial memory impairment and hippocampal neuroinflammation in beta-amyloid rat model of Alzheimer's disease. Journal of neuroinflammation 9: 202.(2012). 
[142] Wang S, Zhang C, Sheng X, Zhang X, Wang B, Zhang G. Peripheral expression of MAPK pathways in Alzheimer's and Parkinson's diseases. Journal of clinical neuroscience : official journal of the Neurosurgical Society of Australasia 21(5): 8104.(2014).

[143] Wang X, Wang W, Li L, Perry G, Lee HG, Zhu X. Oxidative stress and mitochondrial dysfunction in Alzheimer's disease. Biochim Biophys Acta 1842(8): 1240-7.(2014).

[144] Keller JN, Hanni KB, Markesbery WR. Impaired proteasome function in Alzheimer's disease. Journal of neurochemistry 75(1): 436-9.(2000).

[145] Nezelof C. [Role of defective intracellular proteolysis in human degenerative diseases]. Bulletin de l'Academie nationale de medecine 196(8): 1587-98; discussion 98.(2012).

[146] Feldhaus P, Fraga DB, Ghedim FV, De Luca RD, Bruna TD, Heluany M, et al. Evaluation of respiratory chain activity in lymphocytes of patients with Alzheimer disease. Metab Brain Dis 26(3): 229-36.(2011).

[147] Leuner K, Schulz K, Schutt T, Pantel J, Prvulovic D, Rhein V, et al. Peripheral mitochondrial dysfunction in Alzheimer's disease: focus on lymphocytes. Mol Neurobiol 46(1): 194-204.(2012).

[148] Kadioglu E, Sardas S, Aslan S, Isik E, Esat Karakaya A. Detection of oxidative DNA damage in lymphocytes of patients with Alzheimer's disease. Biomarkers 9(2): 203-9.(2004).

[149] Leutner S, Schindowski K, Frolich L, Maurer K, Kratzsch T, Eckert A, et al. Enhanced ROS-generation in lymphocytes from Alzheimer's patients. Pharmacopsychiatry 38(6): 312-5.(2005). 
[150] Mecocci P, Polidori MC, Cherubini A, Ingegni T, Mattioli P, Catani M, et al. Lymphocyte oxidative DNA damage and plasma antioxidants in Alzheimer disease. Arch Neurol 59(5): 794-8.(2002).

[151] Migliore L, Fontana I, Trippi F, Colognato R, Coppede F, Tognoni G, et al. Oxidative DNA damage in peripheral leukocytes of mild cognitive impairment and AD patients. Neurobiol Aging 26(5): 567-73.(2005).

[152] Calabrese V, Sultana R, Scapagnini G, Guagliano E, Sapienza M, Bella R, et al. Nitrosative stress, cellular stress response, and thiol homeostasis in patients with Alzheimer's disease. Antioxid Redox Signal 8(11-12): 1975-86.(2006).

[153] Mangialasche F, Westman E, Kivipelto M, Muehlboeck JS, Cecchetti R, Baglioni M, et al. Classification and prediction of clinical diagnosis of Alzheimer's disease based on MRI and plasma measures of alpha-/gamma-tocotrienols and gamma-tocopherol. J Intern Med 273(6): 602-21.(2013).

[154] Rinaldi P, Polidori MC, Metastasio A, Mariani E, Mattioli P, Cherubini A, et al. Plasma antioxidants are similarly depleted in mild cognitive impairment and in Alzheimer's disease. Neurobiol Aging 24(7): 915-9.(2003).

[155] Cecchi C, Latorraca S, Sorbi S, Iantomasi T, Favilli F, Vincenzini MT, et al. Gluthatione level is altered in lymphoblasts from patients with familial Alzheimer's disease. Neurosci Lett 275(2): 152-4.(1999).

[156] Sultana R, Mecocci P, Mangialasche F, Cecchetti R, Baglioni M, Butterfield DA. Increased protein and lipid oxidative damage in mitochondria isolated from lymphocytes from patients with Alzheimer's disease: insights into the role of oxidative stress in Alzheimer's disease and initial investigations into a potential biomarker for this dementing disorder. J Alzheimers Dis 24(1): 77-84.(2011). 
[157] Cecchi C, Fiorillo C, Sorbi S, Latorraca S, Nacmias B, Bagnoli S, et al. Oxidative stress and reduced antioxidant defenses in peripheral cells from familial Alzheimer's patients. Free Radic Biol Med 33(10): 1372-9.(2002).

[158] Schuessel K, Frey C, Jourdan C, Keil U, Weber CC, Muller-Spahn F, et al. Aging sensitizes toward ROS formation and lipid peroxidation in PS1M146L transgenic mice. Free Radic Biol Med 40(5): 850-62.(2006).

[159] Damjanac M, Page G, Ragot S, Laborie G, Gil R, Hugon J, et al. PKR, a cognitive decline biomarker, can regulate translation via two consecutive molecular targets p53 and Redd1 in lymphocytes of AD patients. J Cell Mol Med 13(8B): 182332.(2009).

[160] Uberti D, Cenini G, Bonini SA, Barcikowska M, Styczynska M, Szybinska A, et al. Increased CD44 gene expression in lymphocytes derived from Alzheimer disease patients. Neurodegener Dis 7(1-3): 143-7.(2010).

[161] Buizza L, Cenini G, Lanni C, Ferrari-Toninelli G, Prandelli C, Govoni S, et al. Conformational altered p53 as an early marker of oxidative stress in Alzheimer's disease. PLoS One 7(1): e29789.(2012).

[162] Casademont J, Miro O, Rodriguez-Santiago B, Viedma P, Blesa R, Cardellach F. Cholinesterase inhibitor rivastigmine enhance the mitochondrial electron transport chain in lymphocytes of patients with Alzheimer's disease. J Neurol Sci 206(1): 23-6.(2003). [163] Gunasingh MJ, Philip JE, Ashok BS, Kirubagaran R, Jebaraj WC, Davis GD, et al. Melatonin prevents amyloid protofibrillar induced oxidative imbalance and biogenic amine catabolism. Life Sci 83(3-4): 96-102.(2008).

[164] Triana-Vidal LE, Carvajal-Varona SM. Protective effect of galantamine against oxidative damage using human lymphocytes: a novel in vitro model. Arch Med Res 44(2): 85-92.(2013). 
[165] Leuner K, Pantel J, Frey C, Schindowski K, Schulz K, Wegat T, et al. Enhanced apoptosis, oxidative stress and mitochondrial dysfunction in lymphocytes as potential biomarkers for Alzheimer's disease. J Neural Transm Suppl(72): 207-15.(2007).

[166] Sultana R, Baglioni M, Cecchetti R, Cai J, Klein JB, Bastiani $\mathrm{P}$, et al. Lymphocyte mitochondria: toward identification of peripheral biomarkers in the progression of Alzheimer disease. Free Radic Biol Med 65: 595-606.(2013).

[167] Bi W, Jing X, Zhu L, Liang Y, Liu J, Yang L, et al. Inhibition of 26S protease regulatory subunit 7 (MSS1) suppresses neuroinflammation. PLoS One 7(5): e36142.(2012)

[168] Pintado C, Gavilan MP, Gavilan E, Garcia-Cuervo L, Gutierrez A, Vitorica J, et al. Lipopolysaccharide-induced neuroinflammation leads to the accumulation of ubiquitinated proteins and increases susceptibility to neurodegeneration induced by proteasome inhibition in rat hippocampus. Journal of neuroinflammation 9(1): 87.(2012).

[169] Wang GP, Khatoon S, Iqbal K, Grundke-Iqbal I. Brain ubiquitin is markedly elevated in Alzheimer disease. Brain research 566(1-2): 146-51.(1991).

[170] Song S, Kim SY, Hong YM, Jo DG, Lee JY, Shim SM, et al. Essential role of E225K/Hip-2 in mediating amyloid-beta neurotoxicity. Molecular cell 12(3): 55363.(2003).

[171] Kudo T, Iqbal K, Ravid R, Swaab DF, Grundke-Iqbal I. Alzheimer disease: correlation of cerebro-spinal fluid and brain ubiquitin levels. Brain research 639(1): 17.(1994).

[172] Ponnappan U. Ubiquitin-proteasome pathway is compromised in CD45RO+ and CD45RA+ T lymphocyte subsets during aging. Experimental gerontology 37(2-3): 35967.(2002). 
[173] Sala SG, Munoz U, Bartolome F, Bermejo F, Martin-Requero A. HMG-CoA reductase inhibitor simvastatin inhibits cell cycle progression at the G1/S checkpoint in immortalized lymphocytes from Alzheimer's disease patients independently of cholesterol-lowering effects. The Journal of pharmacology and experimental therapeutics 324(1): 352-9.(2008).

[174] Blandini F, Sinforiani E, Pacchetti C, Samuele A, Bazzini E, Zangaglia R, et al. Peripheral proteasome and caspase activity in Parkinson disease and Alzheimer disease. Neurology 66(4): 529-34.(2006).

[175] Ullrich C, Mlekusch R, Kuschnig A, Marksteiner J, Humpel C. Ubiquitin enzymes, ubiquitin and proteasome activity in blood mononuclear cells of MCI, Alzheimer and Parkinson patients. Curr Alzheimer Res 7(6): 549-55.(2010).

[176] Magnani M, Crinelli R, Bianchi M, Antonelli A. The ubiquitin-dependent proteolytic system and other potential targets for the modulation of nuclear factor-kB (NF-kB). Current drug targets 1(4): 387-99.(2000).

[177] Hayden MS, Ghosh S. Shared principles in NF-kappaB signaling. Cell 132(3): 344-62.(2008).

[178] Kaltschmidt B, Heinrich M, Kaltschmidt C. Stimulus-dependent activation of NFkappaB specifies apoptosis or neuroprotection in cerebellar granule cells. Neuromolecular medicine 2(3): 299-309.(2002).

[179] Kaltschmidt B, Uherek M, Volk B, Baeuerle PA, Kaltschmidt C. Transcription factor NF-kappaB is activated in primary neurons by amyloid beta peptides and in neurons surrounding early plaques from patients with Alzheimer disease. Proceedings of the National Academy of Sciences of the United States of America 94(6): 26427.(1997). 
[180] Wu Q, Combs C, Cannady SB, Geldmacher DS, Herrup K. Beta-amyloid activated microglia induce cell cycling and cell death in cultured cortical neurons. Neurobiol Aging 21(6): 797-806.(2000).

[181] Zablocka A, Siednienko J, Mitkiewicz M, Gorczyca WA, Lisowski J, Janusz M. Proline-rich polypeptide complex (PRP) regulates secretion of inflammatory mediators by its effect on NF-kappaB activity. Biomedicine $\&$ pharmacotherapy $=$ Biomedecine $\&$ pharmacotherapie 64(1): 16-20.(2010).

[182] Galimberti D, Schoonenboom N, Scheltens P, Fenoglio C, Bouwman F, Venturelli E, et al. Intrathecal chemokine synthesis in mild cognitive impairment and Alzheimer disease. Arch Neurol 63(4): 538-43.(2006).

[183] Hochstrasser T, Marksteiner J, Defrancesco M, Deisenhammer EA, Kemmler G, Humpel C. Two Blood Monocytic Biomarkers (CCL15 and p21) Combined with the Mini-Mental State Examination Discriminate Alzheimer's Disease Patients from Healthy Subjects. Dementia and geriatric cognitive disorders extra 1(1): 297309.(2011).

[184] Kim SM, Song J, Kim S, Han C, Park MH, Koh Y, et al. Identification of peripheral inflammatory markers between normal control and Alzheimer's disease. BMC neurology 11: 51.(2011).

[185] Kusdra L, Rempel H, Yaffe K, Pulliam L. Elevation of CD69+ monocyte/macrophages in patients with Alzheimer's disease. Immunobiology 202(1): 26-33.(2000).

[186] Mruthinti S, Schade RF, Harrell DU, Gulati NK, Swamy-Mruthinti S, Lee GP, et al. Autoimmunity in Alzheimer's disease as evidenced by plasma immunoreactivity against RAGE and Abeta42: complication of diabetes. Curr Alzheimer Res 3(3): 22935.(2006). 
[187] Parker DC, Mielke MM, Yu Q, Rosenberg PB, Jain A, Lyketsos CG, et al. Plasma neopterin level as a marker of peripheral immune activation in amnestic mild cognitive impairment and Alzheimer's disease. International journal of geriatric psychiatry 28(2): 149-54.(2013).

[188] Pellicano M, Bulati M, Buffa S, Barbagallo M, Di Prima A, Misiano G, et al. Systemic immune responses in Alzheimer's disease: in vitro mononuclear cell activation and cytokine production. J Alzheimers Dis 21(1): 181-92.(2010).

[189] Zhang R, Miller RG, Madison C, Jin X, Honrada R, Harris W, et al. Systemic immune system alterations in early stages of Alzheimer's disease. Journal of neuroimmunology 256(1-2): 38-42.(2013).

[190] Zhang W, Wang LZ, Yu JT, Chi ZF, Tan L. Increased expressions of TLR2 and TLR4 on peripheral blood mononuclear cells from patients with Alzheimer's disease. J Neurol Sci 315(1-2): 67-71.(2012).

[191] Walter S, Letiembre M, Liu Y, Heine H, Penke B, Hao W, et al. Role of the tolllike receptor 4 in neuroinflammation in Alzheimer's disease. Cellular physiology and biochemistry : international journal of experimental cellular physiology, biochemistry, and pharmacology 20(6): 947-56.(2007).

[192] Ray S, Britschgi M, Herbert C, Takeda-Uchimura Y, Boxer A, Blennow K, et al. Classification and prediction of clinical Alzheimer's diagnosis based on plasma signaling proteins. Nature medicine 13(11): 1359-62.(2007).

[193] Schwartz M, Baruch K. Breaking peripheral immune tolerance to CNS antigens in neurodegenerative diseases: Boosting autoimmunity to fight-off chronic neuroinflammation. Journal of autoimmunity2014).

[194] Kipnis J, Cohen H, Cardon M, Ziv Y, Schwartz M. T cell deficiency leads to cognitive dysfunction: implications for therapeutic vaccination for schizophrenia and 
other psychiatric conditions. Proceedings of the National Academy of Sciences of the United States of America 101(21): 8180-5.(2004).

[195] Radjavi A, Smirnov I, Kipnis J. Brain antigen-reactive CD4+ T cells are sufficient to support learning behavior in mice with limited T cell repertoire. Brain, behavior, and immunity 35: 58-63.(2014).

[196] Ron-Harel N, Segev Y, Lewitus GM, Cardon M, Ziv Y, Netanely D, et al. Agedependent spatial memory loss can be partially restored by immune activation. Rejuvenation research 11(5): 903-13.(2008).

[197] Gimenez-Llort L, Mate I, Manassra R, Vida C, De la Fuente M. Peripheral immune system and neuroimmune communication impairment in a mouse model of Alzheimer's disease. Annals of the New York Academy of Sciences 1262: 7484.(2012).

[198] Oddo S, Caccamo A, Shepherd JD, Murphy MP, Golde TE, Kayed R, et al. Triple-transgenic model of Alzheimer's disease with plaques and tangles: intracellular Abeta and synaptic dysfunction. Neuron 39(3): 409-21.(2003).

[199] Pizza V, Agresta A, D'Acunto CW, Festa M, Capasso A. Neuroinflamm-aging and neurodegenerative diseases: an overview. CNS \& neurological disorders drug targets 10(5): 621-34.(2011).

[200] Martorana A, Bulati M, Buffa S, Pellicano M, Caruso C, Candore G, et al. Immunosenescence, inflammation and Alzheimer's disease. Longevity \& healthspan 1: 8.(2012).

[201] Jozwik A, Landowski J, Bidzan L, Fulop T, Bryl E, Witkowski JM. Beta-amyloid peptides enhance the proliferative response of activated CD4CD28 lymphocytes from Alzheimer disease patients and from healthy elderly. PLoS One 7(3): e33276.(2012). 
[202] Morris G, Maes M. Oxidative and Nitrosative Stress and Immune-Inflammatory Pathways in Patients with Myalgic Encephalomyelitis (ME)/Chronic Fatigue Syndrome (CFS). Current neuropharmacology 12(2): 168-85.(2014). 


\section{Legend to Figure 1}

\section{Figure 1}

\section{Communication between the CNS and the immune system: Changes in signaling pathways in AD lymphocytes.}

As the consequence of chronic neuroinflammation and neurodegeneration, A $\beta$ peptides and pro-inflammatory mediators can reach the blood through altered BBB. The CNSderived molecules could then induce changes in key signaling pathways that control the survival/death lymphocyte's fate. Conversely, increased production of cytokines and chemokines by activated lymphocytes may impact the CNS contributing to exacerbate the neuroimflammation. Robust arrows denote reported activation in lymphocytes derived from $\mathrm{AD}$ patients. 


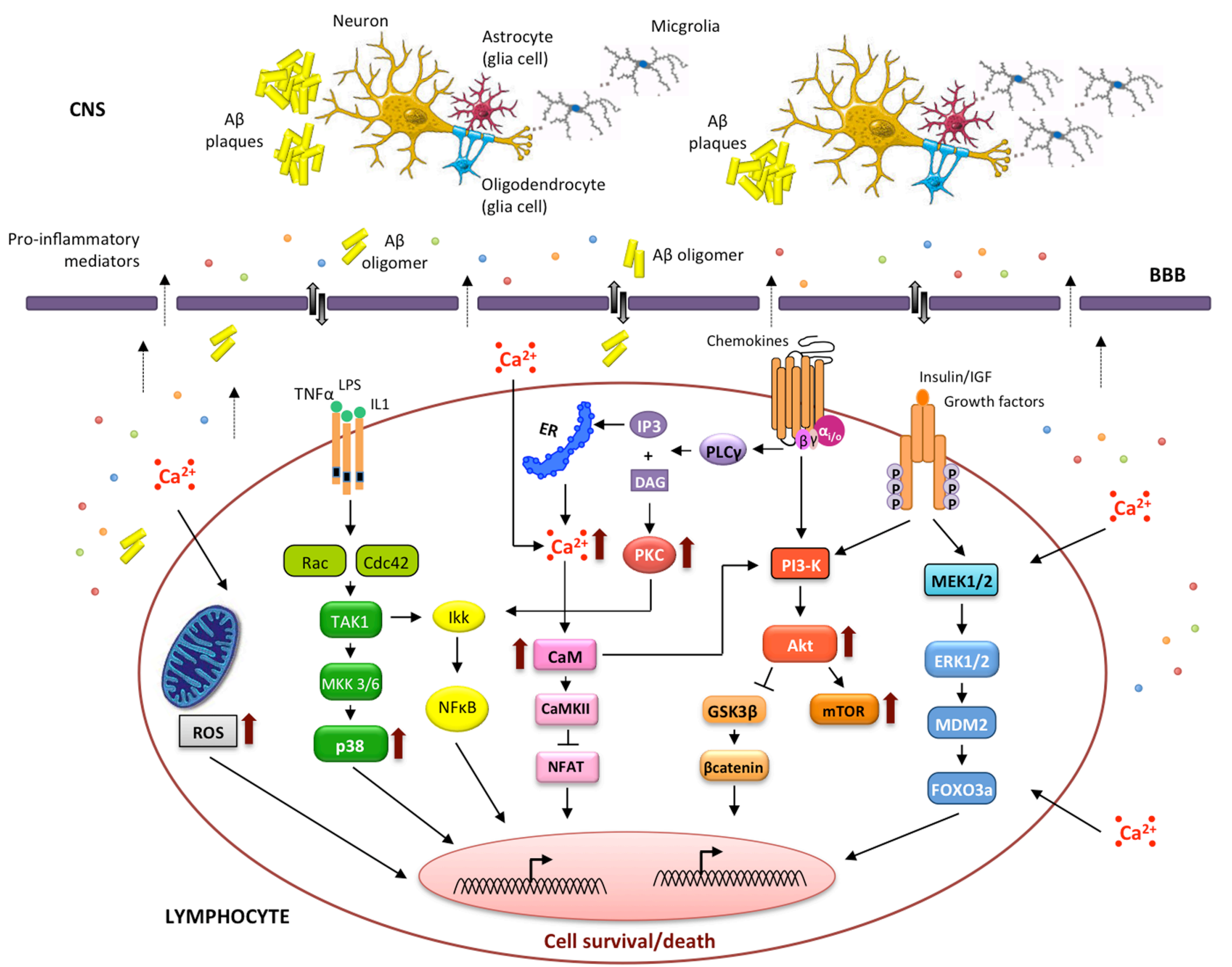

Figure 1 